\title{
HYDROPYROLYSIS OF OIL SHALE
}

\author{
Adnan M. Khalil \\ Al- Balqa' Applied University, Faculty of Engineering Technology, \\ Department of Industrial Chemical Engineering , P.O. Box, 15008, Marka \\ 11134 , Amman, Jordan \\ E-mail: $\underline{\text { dr adnan khalil@hotmail.com }}$
}

(Received July 6, 2006 Accepted August 26, 2006)

\begin{abstract}
Oil shale from Ellajjun area southern region of Jordan hydrogenated at different conditions. The impact of temperature on weight loss and product distribution was investigated. The experimental runs were conducted at different temperatures. Hydrogen gas introduced after purging to the retort with nitrogen thus; to avoid oxidization during heating process. A circulating coolant at $2{ }^{\circ} \mathrm{C}$ cooled the products. The non-condensable gases were released to the open atmosphere whereas the condensed liquid collected and sent for simple atmospheric distillation at laboratories of Jordan Petroleum Refinery.

The rate of weight loss was increased as the temperature increased and the total oil yield increased with increasing temperature at constant hydrogen flow rate. The increasing of reaction temperature resulted in more volume distilled.

The effect of temperature on product distribution of the produced shale oil was investigated, the increase in temperature resulted increased the kerosene and residue amount, and a decrease in the amount of diesel, mean while it has no effect on the gasoline - naphtha fraction.

The sulfur content of the liquid product was influenced by the presence of hydrogen in reaction environment. The amount of sulfur was increased with the increase of temperature at constant hydrogen flow rate.
\end{abstract}

KEYWORDS: Oil Shale, fixed bed, Sulfur, Distillation, Hydropyrolysis.

\section{INTRODUCTION}

The recent souring in oil prices to more than US $70 \$$ has enacted several countries to look into the economics and the utilization of oil shale deposits. The 2005 Energy Act by the United States of America has given the green light to researches and designers to focus their attention on huge deposits of American oil shale. It has become duty on the onus of governments that have large proved deposits of oil shale to explore the various exploitation methods. In China, as an example, Fushun Oil Shale Retorting Plant - came into operation in 1992 under the management of the Fushun Bureau of mines. Its 60 retorts annually produce 60000 tones of shale oil to be sold as fuel oil, with carbon black as a by-product. 
Jordanian oil shale deposits are generally of quite good quality, with relatively low ash and moisture contents but exceptionally high sulfur content (up to $9 \%$ by weight). Gross calorific value $(7.5 \mathrm{MJ} / \mathrm{kg}$ ) and oil yield $(8-12 \%)$; the reserves are exploitable by opencast mining and are easily accessible. There are extremely large proven and exploitable reserves of oil shale in the central and northwestern regions of the country. The proven amount of oil shale in situ is reported bye National Resources Authority, Government of Jordan to be 40 billion tons; proved recoverable reserves of shale oil are 4 billion tons, with estimated additional reserves of 20 billion tons.

Several researchers using fixed bed fluidized bed reactors [1-6] have studied pyrolysis of Ellajjun oil shale. Those workers had used nitrogen to drive out the generated hydrocarbons and volatile matter away from the reaction zone.

In this research, we have investigated the influence of hydrogen presence as sweeping gas during kerogen decomposition reactions, and the product distribution of oil shale hydropyrolysis in $380-620^{\circ} \mathrm{C}$ temperature range. The boiling range and volume percentage of shale oil fractions distilled at atmospheric pressure, compared with fractions produced under the influence of nitrogen sweep gas.

If a technology can be developed to economically recover oil from oil shale, the potential is tantalizingly enormous. If the containing organic material could be converted to oil, the quantities would be far beyond all known convectional oil reserves. Oil shale in great quantities exists worldwide: including in Australia, Brazil, Canada, China, Estonia, France, Russia, Scotland, South Africa, Spain, Sweden and the USA.

The term "oil shale" is a misnomer. It does not contain oil nor is it commonly shale. The organic material is chiefly kerogen, and the "shale is usually a relatively hard rock, called marl. Properly processed, kerogen can be converted into a substance somewhat similar to petroleum. However, it has not gone the "oil window" of heat (nature's way of producing oil) and therefore, to be changed into an oil-like substance, it must be heated to a high temperature. By this process the organic material can be converted into a liquid, which must be further processed to produce an oil which is said to be better than the lowest grade of oil produced from convectional oil deposits.

There are two convectional approaches to oil shale processing. In one, the shale is fractured in-situ and heated to obtain gases and liquids by wells. The second is by mining, transporting, and heating the shale to about $500{ }^{\circ} \mathrm{C}$, adding hydrogen to the resulting product, and disposing of and stabilizing the waste. Both processes use considerable water. The total energy and water requirements together with environmental and monetary costs (to produce shale oil in significant quantities) have so far made production uneconomic. During and following the oil crisis of the 1970's, major oil companies, working on some of the richest oil shale deposits in the world in western United States, spent several billion dollars in various unsuccessful attempts to commercially extract shale oil.

Oil shale has been burned directly as a very low grade, high ash-content fuel in a few countries such as Estonia, whose energy economy remains dominated by shale. Minor quantities of oil have been from oil shale in several countries at times over many years.

Perhaps oil shale will eventually find a place in the world economy, but the energy demands of blasting, transport, crushing, heating and adding hydrogen, together 
with the safe disposal of huge quantities of waste material, are large. On a small scale, and with good geological and other favorable conditions, such as water supply, oil shale may make a modest contribution but so far shale oil remains the "elusive energy".

Oil retorted from oil shale through heating the original raw material. The part of the raw rock that contains and considered to be the source of shale oil is called kerogen. Kerogen is the residue of organic and inorganic compounds which deposited as rock due to high heat and pressure, in other words, it is defined as insoluble organic matter in sedimentary rocks. Kerogen suggested average molecular weight of over 3000 and its empirical formula is $\mathrm{C}_{200} \mathrm{H}_{300} \mathrm{SN}_{5} \mathrm{O}_{11}$; these molecules tied up to each other by oxygen and sulfur cross-linking.

Hydrogenation is a chemical reaction in which unsaturated bonds between carbon atoms reduced by attachment of a hydrogen atom to each carbon. Numerous important applications are found in the pharmaceutical and petrochemical industries. In addition, hydrogenation could be partial i.e. increasing the hydrogen atoms attached to the carbon atom that means reducing the number of unsaturated bonds in the compound undergoing hydrogenation.

In petroleum industry, the importance of hydrogen emanates from the ability of hydrogen atoms to replace sulfur atoms in several sulfur containing compounds found in crude oil. The desulphurization unit presence in refineries is imperative to alleviate the effect of sulfur on the nickel catalyst that used in the various refinery processes. Hence, pyrolysis of oil shale under the influence of hydrogen environment could have indirect impact on the quality and type of produced chemicals.

\section{EXPERIMENTS}

Oil shale sample from Ellajjun area southern region of Jordan was studied and investigated in this research work.

Oil shale samples under investigation, were grinded and sieved to the particle size $\left(d_{p}\right)$ in the range $0.5-3 \mathrm{~mm}$. All samples used as received after crushing to the appropriate size.

All experiments conducted in a stainless steel fixed bed reactor. A $600 \mathrm{~g}$ of oil shale sample was electrically heated in $800 \mathrm{~cm}^{3}$ volume cylindrical retort. Nitrogen gas feed rate was maintained until about $200^{\circ} \mathrm{C}$ then hydrogen was switched on at $100 \mathrm{~cm}^{3}$ per minute flow rate. The hydropyrolysis runs were conducted in $380^{\circ} \mathrm{C}$ and $620^{\circ} \mathrm{C}$ temperature range. To fractionate shale oil in a simple atmospheric distillation, 500 $\mathrm{cm}^{3}$ needed for each temperature. The required quantities of oil for distillation collected at 470,520 and $540{ }^{\circ} \mathrm{C}$ temperatures. The evolved hydrocarbon and the noncondensable gases were cooled through coolant maintained at $2 \pm 2{ }^{\circ} \mathrm{C}$. The light gases vented to atmosphere and the collected liquid of hydrocarbon taken for distilled.

\section{RESULTS AND DISCUSSION}

\section{Weight Loss And Yield Results}

This work involved measuring the total weight loss of oil shale samples with temperature. Several experimental runs were conducted to calculate the total weight loss of samples in a fixed bed retort. 600 grams of oil shale used in each run. The sizes 
of particles in this investigation were selected based on mass transfer and diffusion free limitation reaction.

Figure 1 indicates the variation of total weight loss as a function of retorting temperature. As it can be seen, the kerogen loss increased with increasing the reaction temperature. Total weight loss is based on the original sample weight as received before retorting and the weight of the spent shale. As shown in the figure, the total loss of sample varies between $11 \%$ and $22 \%$ in the studied range of reaction temperatures. This total weight loss includes loss of intermolecular water, volatiles and liquid hydrocarbons. The studied experimental temperatures were in the range of $380^{\circ} \mathrm{C}$ and $620{ }^{\circ} \mathrm{C}$.

As reported by several workers [7], the total percent weight loss of the oil shale is divided into three regions. The loss of intermolecular water is the characteristic of the first region, which lies below $250{ }^{\circ} \mathrm{C}$. The water is associated with the mineral clay of the shale oil sample, and it is liberated during the heating process. The hydrocarbon evolution region lies in the range $250{ }^{\circ} \mathrm{C}$ to about $530{ }^{\circ} \mathrm{C}$, at which hydrocarbons content of kerogen are destructively distilled during retorting, and finally, the mineral decomposition of calcium carbonate and dolomite stage, which occur in $530{ }^{\circ} \mathrm{C}-810^{\circ} \mathrm{C}$ temperature range.

The effect of reaction temperature on the oil yield is indicated in Figure 2. It is quite clear that increasing the pyrolysis temperature in presence of hydrogen atmosphere increase in the oil yield, in addition, the oil yield increases with the increase the total weight loss of the kerogen; Ekinci and co-workers [8] reported similar results. The oil yield is measured as the amount of collected oil in each experiment with respect to Fischer Assay measurement. The increase in shale oil is linear in the studied experimental conditions.

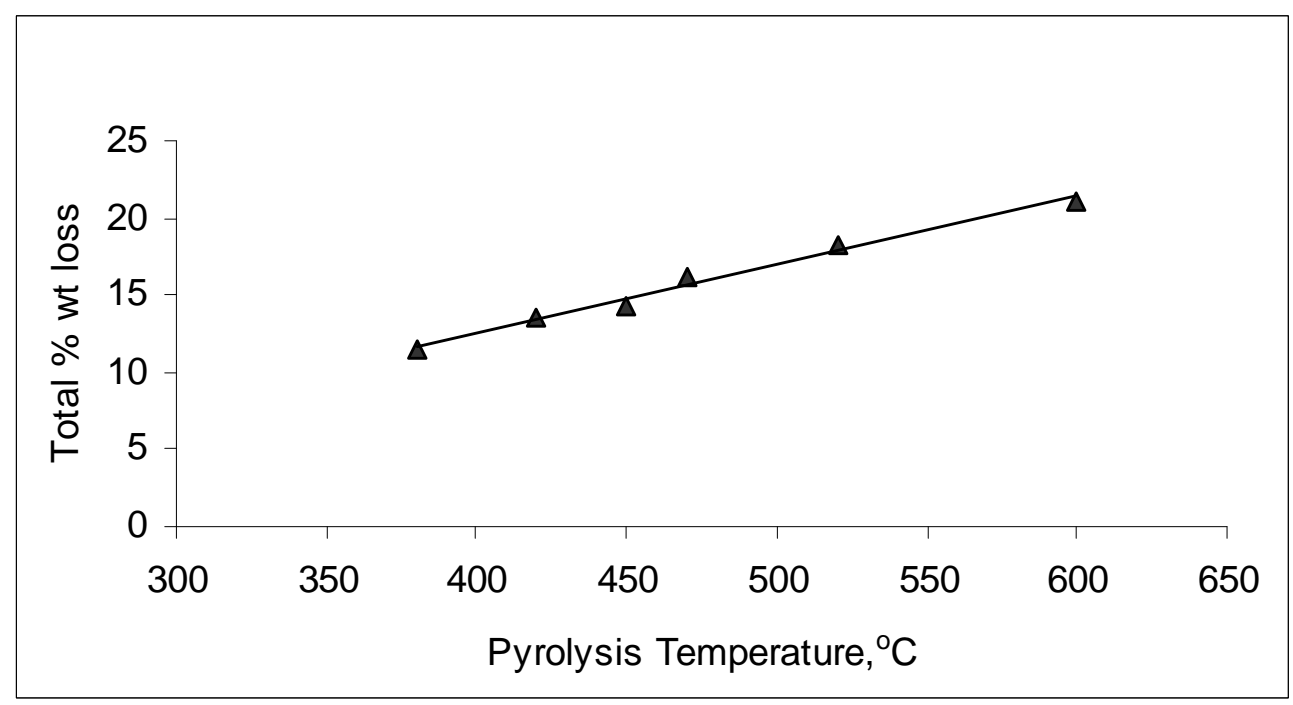

Figure 1: Effect of temperature on the total weight loss of oil shale. 


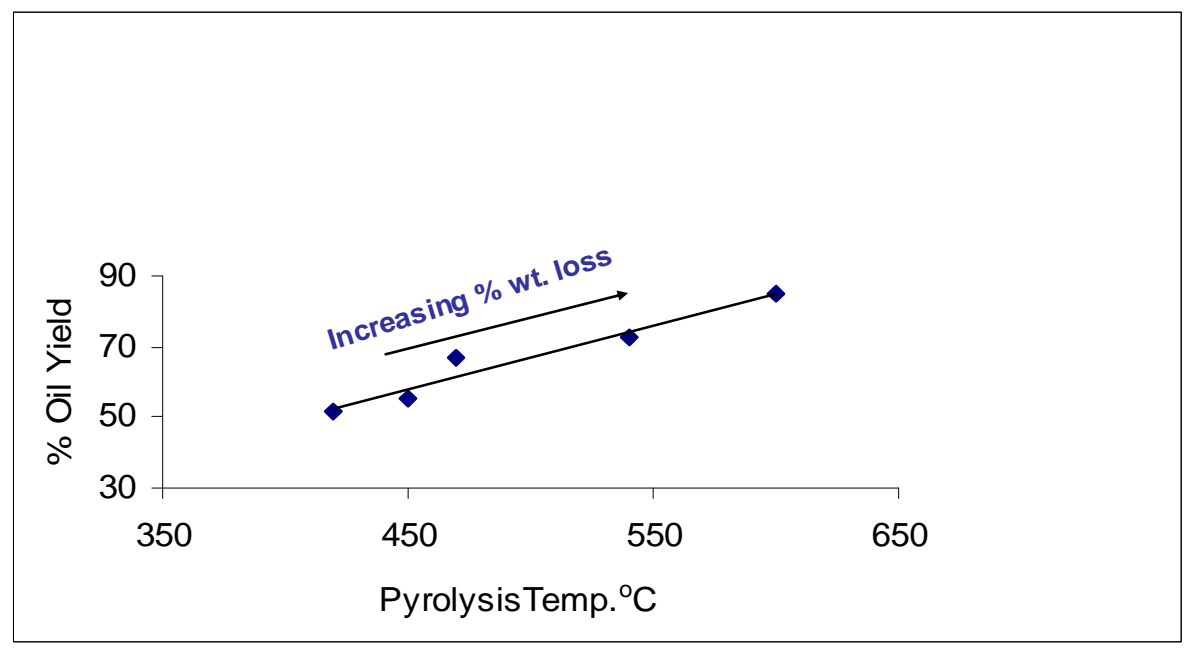

Figure 2: Effect of pyrolysis temperature on shale oil yield.

The oil yield dependency on the total kerogen weight loss is indicated in Figure 3. As it can be seen, the oil yield was increased with increasing total weight loss of sample. In addition, it is clear that the total oil yield was increased with increasing temperature in conjunction with increasing weight loss. The maximum oil yield was obtained at the highest experimental temperature in this work.

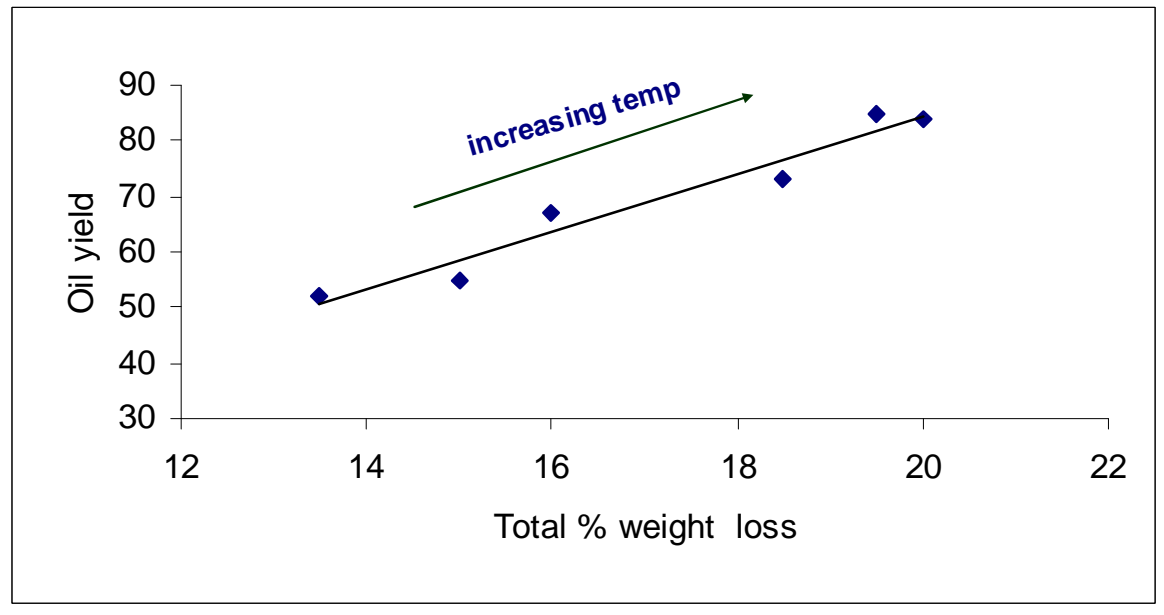

Figure 3: Relationship of oil yield with total kerogen weight loss .

\section{Shale Oil Distillation}

In order to distillate the shale oil produced during retorting, three selected temperatures were chosen for distillation results since a minimum quantity of $500 \mathrm{~cm}^{3}$ is necessary for simple atmospheric distillation apparatus. The three selected temperatures were 470,520 and $540{ }^{\circ} \mathrm{C}$. The true boiling range is shown in Figure 4. 
As it can be seen, the general trend of the increasing volume percent with temperature is obvious for all the temperatures. The initial boiling point varied from 108 to $115^{\circ} \mathrm{C}$, which is a function of the retorting temperatures. On the other hand, the end point where $80 \%$ of the volume were distilled varied from 356 to $366{ }^{\circ} \mathrm{C}$. The variation in the initial and final boiling temperatures is in correspondence with the retorting temperatures. It is clear from the figure, that the volume percent distilled at $520{ }^{\circ} \mathrm{C}$ is lower than that for 470 and $540{ }^{\circ} \mathrm{C}$. This behavior is attributed to secondary cracking reactions that are taking place at higher temperatures; in addition, the presence of hydrogen in the surrounding environment enhanced the production of lighter hydrocarbons. This, results in more of gaseous products leaving behind heavier hydrocarbon components of higher boiling range as shown in Fig. 4.

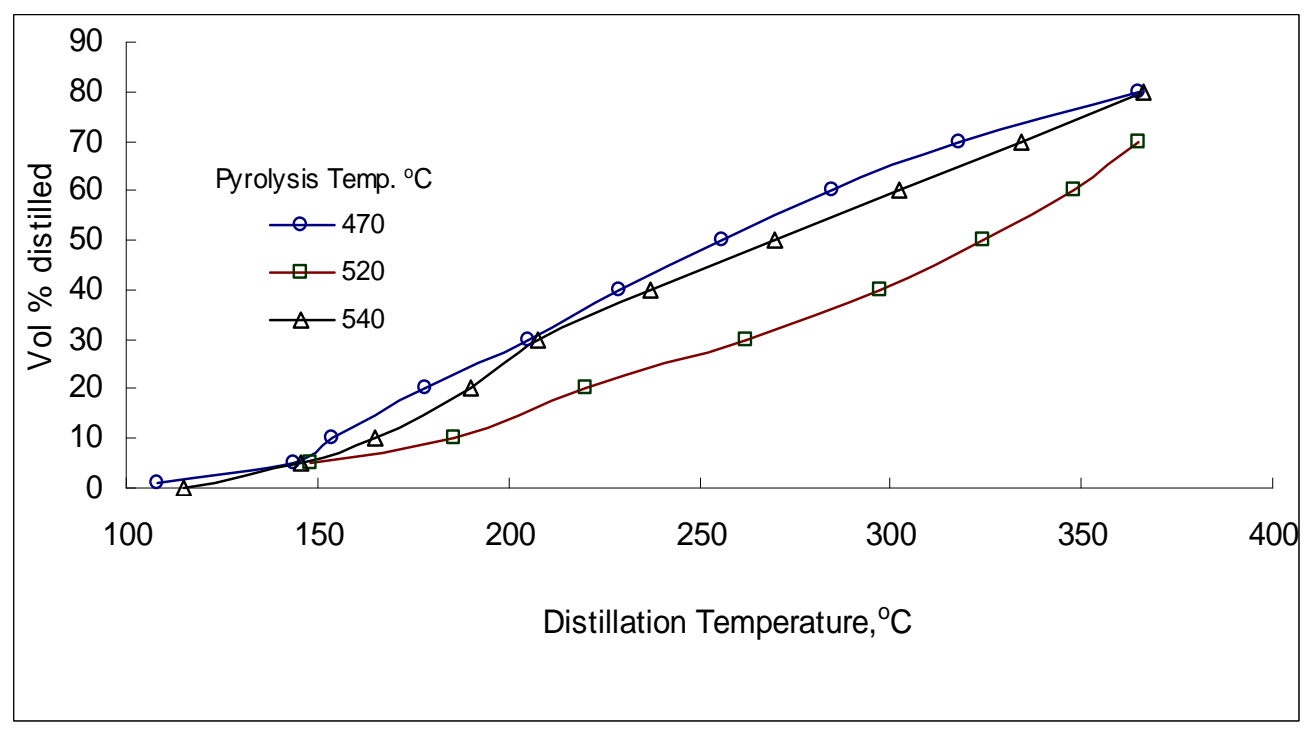

Figure 4: Volume percent distilled against distillation temperature.

Further analysis of the hydropyrolysised products, indicates that $5 \%$ by volume of the distilled oil lies in the gasoline-naphtha fraction. The gasoline-naphtha fraction is characterized by $\mathbf{0}-\mathbf{1 4 0}^{\circ} \mathrm{C}$ boiling range. On the other hand, the kerosene cut constitutes $45 \%$ of the total fractioned amount that characterized by $140-250{ }^{\circ} \mathrm{C}$ boiling range. The diesel makes up the $30 \%$ of the produced volume while $20 \%$ was residue with boiling temperature higher than $370{ }^{\circ} \mathrm{C}$.

Figure 5 shows the effect of hydrogen presence in the reaction zone on the product distribution. As it can be seen, the sweeping gas has no effect on the amount of gasoline and naphtha produced, while hydrogen presence as sweeping gas has increased the amount of kerosene by $50 \%$. On the contrary, the amount of diesel was decreased by $50 \%$ compared with similar experimental conditions in presence of nitrogen. The shift in the product distribution is attributed to the effects of hydrogen during retorting on the rate of weight loss during kerogen decomposition and its role during secondary reactions. In addition, the effect of sweeping gas on the residue indicated in the figure. 


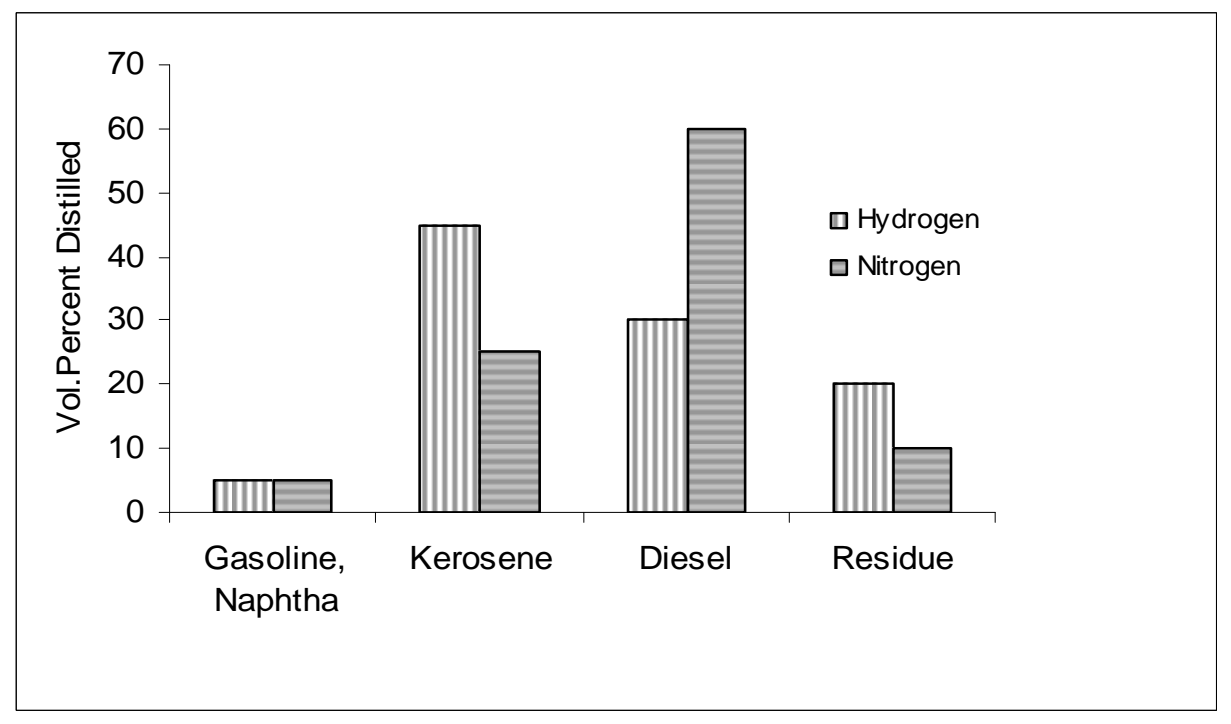

Figure 5: Product distribution of the produced shale oil.

\section{Sulfur}

It is known that the generated shale oil during retorting of oil shale contains high percent of sulfur. The sulfur content was determined using x-ray fluorescence. The obtained sulfur content weight percent value of the produced shale oil for same reaction temperature at different sweep gases depicted in Figure 6. The weight percent of sulfur in the produced oil has increased with the nature and type of sweep gas used in the experiment. As it can be seen, the hydrogen presence in the reaction environment has leached more sulfur from the kerogen compared with nitrogen and combine steam with nitrogen. Nitrogen is inactive inert material, while steam in presence of active catalyzing components of the oil shale such as $\mathrm{SiO}_{2}, \mathrm{Al}_{2} \mathrm{O}_{3}$ and other oxides catalyzes reactions of sulfur transfer and other hydrocarbon reactions of kerogen to shale oil. These reactions are enhanced in the presence of active sweeping gas such as steam and hydrogen. The increase in sulfur content of shale oil as shown in Figures 5, 6 is in accordance with increasing activity of the sweeping gas, nitrogen; nitrogen-steam mixture hydrogen.

\section{CONCLUSIONS}

Hydropyrolysis of oil shale can be conducted at different reaction temperatures under the influence of hydrogen sweeping gas. The reaction environment has a direct effect on the amount of oil produced and affects on the product distribution. The total weight loss of samples was increased with the amount of $\mathrm{H}_{2}$ added; in addition, higher reaction temperature gave higher kerogen decomposition rate.

In simple atmospheric distillation, fraction of kerosene was increased by $50 \%$ when using hydrogen as carrier gas compared with nitrogen sweep gas. This increase is associated with a decrease in diesel fraction amount and higher residue.

Organic sulfur in the produced oil is more in the case of hydrogen sweeping gas compared with nitrogen and water vapor sweeping mediums. 


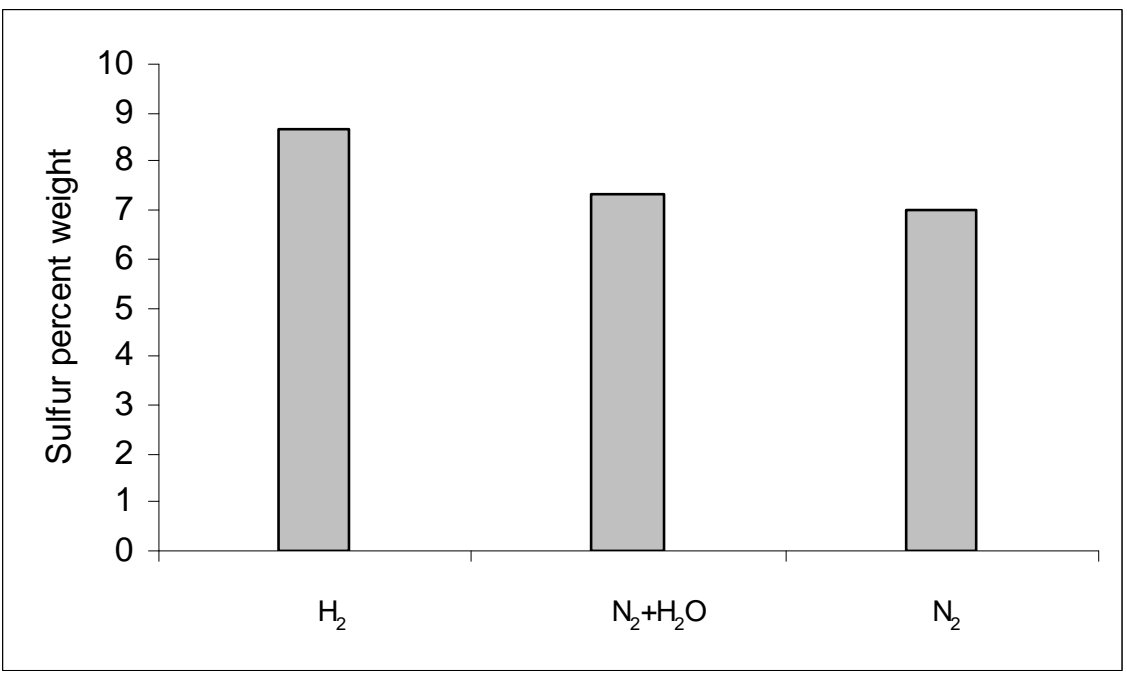

Figure 6: Effect of sweep gas on the weight percent of sulfur in shale oil.

\section{REFERENCES}

[1] O.S. Al-Ayed, Journal of Engineering Science, 33, No.4, (2005), 1477-1785

[2] O.S. Al-Ayed, Journal of Engineering Science, 34, No.1, (2006), 275-281

[3] O.S. Al-Ayed, International Green Energy Conference, Ontario, Canada, 2006.

[4] J.M. Nazzal and P.T. Williams, Int. J. Energy Res. 26, (2002), 1207-1219.

[5] J.O. Jaber, S.D. Probert, and P.T. Williams, Energy, 24, (1999), 761-781.

[6] J.O. Jaber, S.D. Probert, Applied Energy, 63, (1999), 269-286.

[7] R.A. Haddadin , F.A. Mizyed, Ind. Eng. Chem. Proc. Des.Dev. 13 (1974), 332-6

[8] E.Ekinci, M. Citiroglu, A. Akar, E.Putun and C.E. Snape. Hydrogen Energy System. 1995, 281-286.

\section{هدرجة الصخر الزيتي}

تمت هدرجة الصخر الزيتي تحت ظروف مختلفة. وقد جرت در اسـة تأثير درجـة

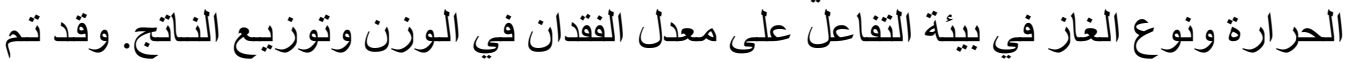

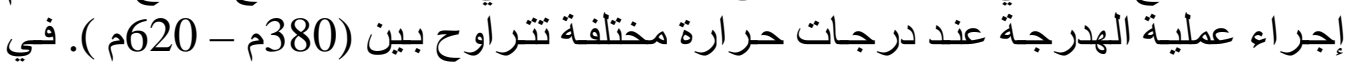

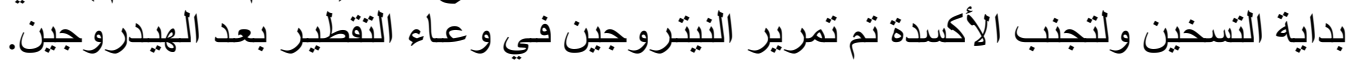

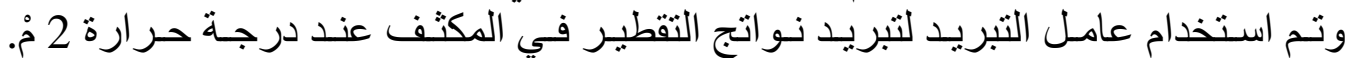

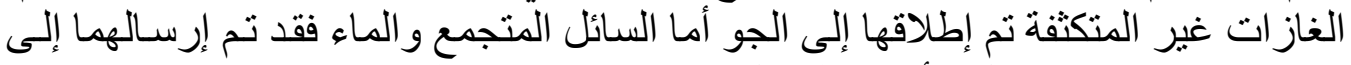
مختبرات مصفاة البترول الأردنية لفصل مكوناتها بالتقطير الجوي البسيط. 
وقد وجد أن معدل فقدان الوزن يتز ايد مـع ارتفاع درجـة الحر ارة كذللك فإن نـاتج

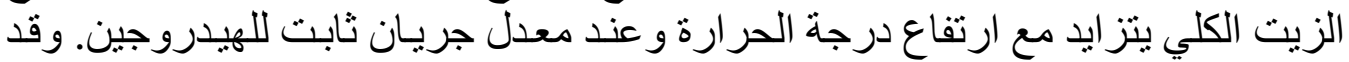

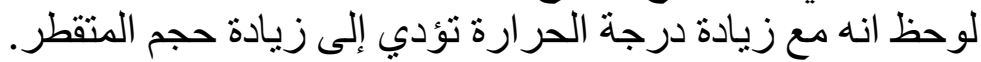

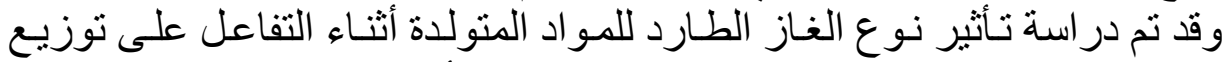

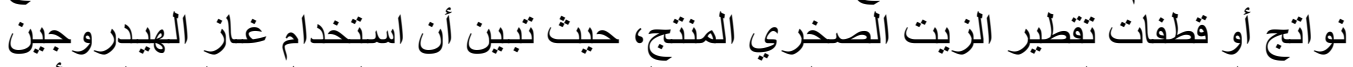

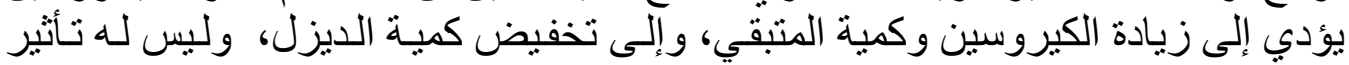

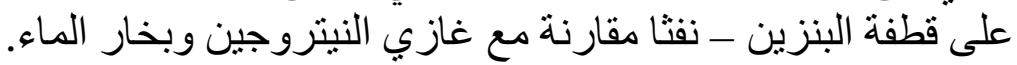

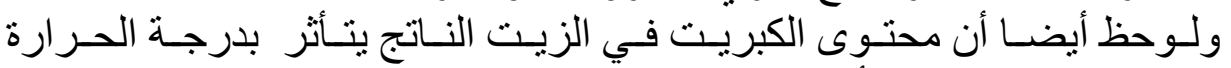

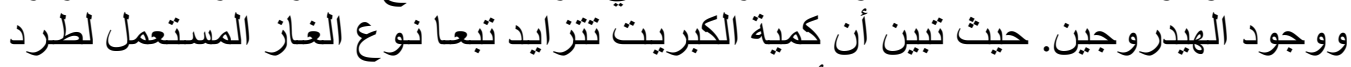

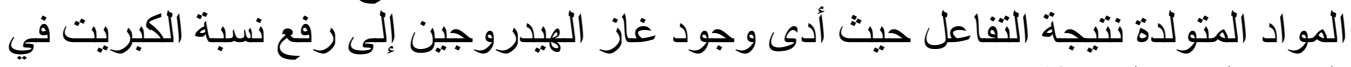

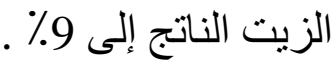

